\title{
A HORA DE REPENSAR O ECA
}

Reis Friede ${ }^{1}$

\section{RESUMO}

O presente artigo analisa criticamente o Estatuto da Criança e do Adolescente, em seu aniversários de 20 anos, propondo uma reflexão acerca da normatização em comento.

Palavras-chave: Estatuto da Criança e do Adolescente. Ineficácia. Legislação. Reflexão.

No presente aniversário de 20 anos da introdução do Estatuto da Criança e do Adolescente - ECA, em nossa legislação, parece-nos, à luz de todas as evidências indicativas, que está mais do que na hora de repensar esta inovadora, - mas ao mesmo tempo, absolutamente ineficaz -, normatização, no âmbito do escopo contextualizante dos próprios resultados negativos que foram observados (e, particularmente, verificados) até o presente momento.

Muito embora seja cediço reconhecer, - em destacado sentido opinativo reverso à presente proposta reflexiva -, a existência de um verdadeiro batalhão de juízes sociólogos, ardentes e apaixonados defensores do ECA, precisamos urgentemente, todavia, nos afastar de toda a passionalidade que naturalmente envolve o assunto para, com maestria lógica, estabelecermos uma verdadeira e imparcial visão crítica (e também amadurecida) sobre o tema vertente, posto que não é difícil deduzir que, em grande medida, foi a ingênua tentativa de se implantar um "Código Suíço" em um País Tropical (em sinérgico desafio a nossa realidade efetiva), - mais do que qualquer outro fator isoladamente considerado -, que conduziu aos extremos absurdos que estamos sendo compelidos a vivenciar diuturnamente.

À guisa de simplório exemplo, basta mencionar, conforme muito bem noticiado pela Folha de São Paulo, em sua edição de 23/10/2009, à p. 13, que um problemático (para se dizer eufemisticamente o mínimo) adolescente de 13 anos chegou a ser detido, em flagrante delito, por 12 vezes, e, após esta última, mais uma vez acabou por ser liberado, em consequência da estrita aplicação dos dispositivos mandamentais consignados no ECA, mesmo após ter praticado toda a sorte de infrações, - incluindo uma tentativa de furto de um carro de um policial militar em Diadema, no ABC; furto consumado de vários outros veículos; dirigir carros e motos roubados, além de participar de um assalto a uma farmácia -, fatos estes que, com toda certeza, somariam muitos anos de prisão (inclusive com efetiva possibilidade de encarceramento) em qualquer outro País Ocidental, de índole político-democrática.

Não é por outro motivo que, cada vez mais, observamos, atônitos, um expressivo e preocupante número de cidadãos brasileiros, vítimas da crescente criminalidade que tomou conta de nossas principais metrópoles, recorrerem, direta 
ou indiretamente, aos "supostos" serviços de proteção dos principais representantes do denominado "Estado Paralelo", (onde a menoridade do infrator é apenas um simplório dado estatístico), objetivando fazer valer, - ainda que por vias moralmente condenáveis (para não adentrarmos em considerações técnico-legais) -, os seus respectivos direitos inalienáveis à segurança pessoal e familiar.

A propósito, não é de hoje, lamentavelmente, que os meios de comunicação noticiam o autêntico império da ordem imposto pelos respectivos "comandante do tráfico (ou afins)" nas comunidades carentes, que representam, hoje, mais do que em qualquer outra época, verdadeiras "micro cidades", em que qualquer prática delituosa (perpetrada ou não por menores de idade) é rapidamente solucionada, ainda que através de métodos brutais -, o que, em grande parte, explica a relativa simpatia que as milícias (estas empregadoras contumazes de menores, inclusive como "substitutos de autoria" de eventuais crimes consumados) experimentaram (pelo menos em um primeiro momento), particularmente, na cidade do Rio de Janeiro.

Ainda assim, e independentemente da existência desta inequívoca realidade, é forçoso concluir, entretanto, que deve haver, por derradeiro, algum tipo de meiotermo entre a justiça (paralela) da barbárie e a justiça (oficial) da impunidade, posto que não parece razoável, - e minimamente aceitável -, que toda a coletividade tenha que se defrontar sistematicamente com o autêntico dilema estabelecido pela práxis social atual no que concerne à escolha entre estes dois extremos radicais.

Muito embora não se possa deixar de reconhecer o inédito, excepcional e corajoso trabalho do governo do Estado do Rio de Janeiro (e, especificamente da Secretaria de Segurança Pública), em especial, no destemido enfrentamento (jamais experimentado no passado na chamada "Cidade Maravilhosa" ou em qualquer outra metrópole verde e amarela), resta evidente que a Sociedade brasileira clama por uma solução definitiva (e, sobretudo, legal) para o problema que, em última análise, a proteja, efetivamente destes verdadeiros desafios titularizados, em grande parte, por pessoas que se presume ainda em formação de caráter (sem uma suposta "compreensão plena" da natureza criminosa de sua conduta), até porque o Brasil, sob este prisma analítico, se apresenta, ipso facto, como o único País do mundo que possui, em absurda e desafiadora lógica dissonante, uma Delegacia (comumente conhecida pela sigla DPCA) cujo objetivo primordial, - expressamente consignado em lei -, é prioritariamente proteger o ofensor (ainda que supostamente "menor de idade") em flagrante detrimento da vítima que, inclusive, pode ser também, vale lembrar, uma simples criança em seus primeiros anos de vida. 


\section{A TIME TO RETHINK THE SCA}

\section{ABSTRACT}

This article critically analyzes the Statute of Children and Adolescents, in his 20 years of birthdays, proposing a reflection on the norms under discussion.

Keywords: Inefficiency. Legislation. Reflection. Statute of Children and Adolescents.

\section{NOTAS}

1 Desembargador Federal e ex-Membro do Ministério Público; Mestre e Doutor em Direito e autor de mais de 30 obras jurídicas. E-mail: reisfreide@augustomottaa.br. Endereço: Tribunal Regional da 2ª Região. Rua Acre, 80 sala 1501 - Centro - 20081-000 Rio de Janeiro, RJ - Brasil.

Recebido para publicação: 16/06/2010

Aceito para publicação: 22/12/2010 